\title{
Keynes's animal spirits vindicated: an analysis of recent empirical and neural data on money illusion
}

\author{
Abstract: <<SUPPLY A BRIEF ABSTRACT / LESS THAN 100 RDS $>>$ \\ Key words: <<SUPPLY A FEW KEY WथS $S>>$
}

Economists have long favored an instrumental approach to money, highlighting the three functions that give it specific utility: a medium of exchange, a store of value, and a unit of account. However, as noted by Akerlof and Shiller (2009), the third function has not been the subject of extensive analysis. Indeed, the first two functions constitute the core demand for money, in relation to income and interest rates, and the emphasis is often placed on the medium of exchange function. Money is thus considered a pure instrument created to facilitate the circulation of goods and services, which was hindered by the difficulties of bartering, in particular, due to the coincidence of wants problem.

Within this analytical framework, money-created by and for exchange-is associated with the idea of homo economicus, whose behavior is limited to maximizing his or her utility function. As money is used only to acquire goods or services or to store value, the rational homo economicus agent is only interested in his or her purchasing power. Hence, money illusion does not exist. Defined as the failure to distinguish between the nominal and the real value of money, or as an inability to accurately take into account the change in money prices, money illusion is indeed manifested in irrational choices.

Sacha Bourgeois-Gironde is $\Omega$ VHAT II UR POSITION / E.G., PROFESSOR? $>>$ at Aix-Marseille 12 rsity, Cepere $<<$ WHAT IS YOUR POSITION? $>>$ at Institut Jean-Nicod (ENS, EHES WHAT DOENS AND EHESS STAND FOR? $\gg$. Marianne Guille is $<<$ WHAT IS YOU OSITION $>>$ at Université Panthéon-Assas, LEM<<WHA DES LEM ST $D$ FOR? $>$. The authors thank Jean-Marie Le Page, Sébastien L nnd an anonymous referee for their helpful comments. 
However, beginning in the early twentieth century, some economists, including notably John Maynard Keynes and Irving Fisher, emphasized the tendency of people to think of money in nominal, rather than real, terms. Fairly well accepted until the end of the 1960s, and used notably to justify the downward stickiness in nominal wages and the real effects of monetary policy, the money illusion hypothesis was nevertheless practically abandoned thereafter as economists broadly adhered to the monetarist school. Driven by the postulate of a rational maximizer agent, this new consensus was described by Tobin (1972) as "[a]n economic theorist can, of course, commit no oreater crime than to assume money illusion," <<PAGE FOR QUOTA N $>$ > and was not challenged for a long time, even by Post Keynesians. Their negative attitude toward money illusion originated from the argument that Keynes was misinterpreted and did not see this illusion as important (Trevithick, 1975).

During the early 1990s, the interest in money illusion was renewed from an empirical standpoint and largely grew out of the influence of experimental psychology applied to economics, which focuses on money illusion as a cognitive bias separating agents from the homo economicus model. Conceding that agents can suffer from money illusion is equivalent to considering that they have bounded rationality, and seeking to cast light on this cognitive bias requires the unit of account function to be studied.

In practical terms, the fact that money serves as a unit of account means that agents think in money terms. Contracts (labor or loan contracts, leases) include clauses labeled in money terms, company accounts are presented in money terms, taxes are paid with money, and so forth. In each of these cases, agents could adjust the nominal quantities so that the use of money as a unit of account would have no real effect. For instance, they could plan for automatic adjustments in line with inflation, via indexation on the general level of prices, but this is generally not the case, as shown by Shiller et al. (1997). A plausible explanation could be that agents suffer from money illusion.

Our paper is aimed at understanding the economic and psychological reality of this phenomenon. In the first section, we review the changing status of money illusion within the field of economic thought. Oscillating between the temptation to prescribe what should be and the desire to make reality intelligible, economists have at times ignored money illusion due to the perfect rationality hypothesis while at other times acknowledging it, in particular in recent empirical studies $<<$ CITE AN $@$ ECENT EXAMPLE(S)? >> of various types. In the second section, we account for recent contributions of experimental economics and neuroeconomics 
that prove particularly suited to understanding the psychological reality of this phenomenon at the level of individual agents.

While psychological and neurobiological data, obtained with a view to understanding our monetary behavior, have thus far had a minimal impact on the analysis of the nature and role of money in economics, it is possible to isolate the neural mechanisms that explain some behavioral anomalies with regard to money. From a psychological and neurobiological standpoint, money is complex in nature and the difficulty lies in successfully identifying a coherent or sufficiently structured mental and neural representation of money. A recent neuroscientific study of money illusion (Weber et al., 2009) shows that money illusion is attributable to the sensitivity of the brain's reward circuit to the nominal frame of money due to its salience. In our view, if money illusion is the result of a neurobiologically anchored dissociation between the perception of money's real value and that of its nominal value, it is more difficult to ignore it on a theoretical level and to define public policies that would dampen its effects on individuals.

\section{Money illusion in economics: from anathema to empirical evidence}

The assumption of rational behavior joined with David Hume's assertion that "money is a veil," with no specific utility except as an instrument for the exchange of commodities that are unlike money of direct significance for economic welfare, precludes any form of money illusion (Of Money, $1752<<$ SUPPLY COMPLETE INFOR @ION FOR THIS CITATION FOR THE REFERENCE LIST>>). In particular, labor supply depends on real, rather than nominal, wages.

These hypotheses, particularly those that describe how the labor market works and postulate the negligible role played by money, were not questioned by the neoclassical economists. ${ }^{1}$ Leontief (1936) specifies that money illusion violates the so-called homogeneity postulate of economic theory, which states that the demand and supply functions should be homogeneous of degree zero in all nominal prices (i.e., they should depend on relative prices and not on absolute or nominal prices). To resolve the problem of the subsequent indetermination of money prices and to integrate the quantity theory of money into the general equilibrium paradigm, Patinkin $(1949,1956)$ extends this reasoning to real balances and specifies that the absence of money illusion is verified

${ }^{1}$ See Pigou (19 
when excess-demand functions for commodities solely depend on relative prices and real balances. Concretely, the absence of money illusion enables the neutral effect of money to be demonstrated: a change in the quantity of money results in a proportional change in all money prices so the purchasing power of money is unchanged; therefore, agents do not modify their supply and demand for commodities.

Nevertheless, some economists, such as Fisher (despite being a quantitativist) and Keynes, consider that agents are in fact predisposed to money illusion and, as a consequence, do not accurately take inflation into account.

Fisher defines money illusion as "the failure to perceive that the dollar, or any other unit of money, expands or shrinks in value" $<<$ Y $\mathbb{E}$ AND PAGE FOR QUOTATION>> attributable to the fact that money as a unit of account is fundamentally different from physical yardsticks, such as miles and kilos, in that it does not have an intrinsic value that is unchanging over time (The Money Illusion, 1928<<SUPPLY OOPLETE INFORMATION FOR THIS CITATION FOR THE REY RENCE LIST $>>$ ). Because of this illusion, agents are unable to correctly take into account changes in prices, that is, to distinguish between a transaction's nominal value and its real value. Hence, they make inappropriate decisions. Fisher attempts to demonstrate the empirical importance of money illusion on the basis of historical and statistical evidence from various countries. He considers money illusion to be a decisive factor in determining business cycle fluctuations.

\footnotetext{
Dis General Theory (1936), Keynes emphasizes the effects of this Wion on workers' behavior. He notes: "ordinary experience tells us, beyond doubt, that a situation where labor stipulates (within limits) for a money-wage rather than a real wage, so far from being a mere possibility, is the normal case. Whilst workers will usually resist a reduction of money-wages, it is not their practice to withdraw their labor whenever there is a rise in the price of wage-goods" (<<SUPPLY SPECIFIC P OP(S) FOR QUOTATION $>>$ ch. 2, II $<<$ WHAT DOES "C PTANI TOR? VOLUME II OF THE COLLECTED WORKS? SUP ITI COMPLETE INFORMATION FOR KEYNES 193 ONERAL THEORY OR COLLECTED WORKS FOR THE REFERTCE LIST $>>)$.
}

In other words, workers are generally opposed to any reduction in nominal wages, whereas they accept more easily a reduction in their real wages due to inflation. The result is downward rigidity or stickiness in nominal wages, which Keynes uses as a pillar of his criticism of the neoclassical labor market theory. Whereas this theory implicitly assumes that workers 
adjust their labor supply in function of every fluctuation of prices, Keynes observes that this is not actually the case and that the workers' tendency to accept moderate decreases of their real wages can increase the volume of employment. Thus, there is no "labor market" in a traditional theoretical sense since supply depends on nominal wages and demand on real wages. Yet Keynes also considers the possibility that entrepreneurs can fall prey to money illusion, at least in the short term, ${ }^{2}$ and recognizes that the impact on employment of changes in money wages are $p$ plex and depend on the expectations they generate (ch. $19<<$ CLAR CITATION / SEE PREVIOUS QUERY >>).

Clearly, Keynes does not believe that workers' money illusion, that is, their passivity in the event of moderate inflation, is sufficient to restore full employment, as the level of employment is more generally determined by the principle of effective demand for goods and services. However, he highlights that a money economy is first and foremost an economy in which agents count in money terms; hence rejects the neoclassical principle of dichotomy and underlies $<<$ CO 2 ECT? OR UNDERLINES MEANT? $>>$ the importance of the signals transmitted by nominal amounts. He thus admits that agents can be subject to money illusion. However, he also justifies the resistance to a reduction in nominal wages by the fact that such a reduction is never generalized and thus implies a de facto relative reduction in real wages, whereas it is more difficult to resist a reduction in real wages resulting from inflation that affects all workers. ${ }^{3}$ Furthermore, Keynes asserts that "if wages were to be fixed in terms of some other commodity, e.g. wheat, it is improbable that they would continue to be sticky" $<<$ S $\mathbb{P}$ LY PAGE FOR QUOTATION / SEE QUERY IN FOOTNOTE $4>>$ and more precisely, he links this stickiness to money's specific properties. ${ }^{4}$ Because "[m]oney in its significant attributes is, above all, a subtle device for linking the present to the future" $<<$ SUH PAGE FOR QUOTATION / SEE QUERY IN FOOTNOTE $\rightarrow$ and because this future is uncertain and impossible to forecast in the long term using a rational

\footnotetext{
2 "For a time at least, rising prices may delude entrepreneurs into increasing employment beyond the level which maximizes their individual profits measured in terms of the product" (ibid., ch. $20<<$ SUPPLY PAGE FOR QUOTE RATHER THAN CHAPTER NUMBER $>>$, III, note $1 .<<$ (IBID WOULD BE 1936 GENERAL THEORY, BUT IF THIS IS VOLUME III, THAT IS A DIFFE DT SUBTITLE AND PERHAPS A DIFFERENT YEAR / CLARIFY SOURC L SUPPLY COMPLETE INFORMATION FOR THE REFERENCE LIST (VOLUME III OF THE COLLECTED WORKS MEANT? >)

${ }^{3}$ Ibid., chapter 2, III.<<CLARIFY SOI PDE / SEE QUERY AT NOTE 2>>

${ }^{4}$ Ibid., chapter 17, III.<<CLARIFY SOURCI E QUERY AT NOTE 2>>
} 
approach, we consider it obvious that money illusion results implicitly from factors that, according to Keynes, nevertheless enable agents to make decisions with an impact on the future. ${ }^{5}$ The primary factor lies in our animal spirits: "it is our innate urge to activity which makes the wheels go round, our rational selves choosing between the alternatives as best we are able, calculating where we can, but often falling back for our motive on whim or sentiment or chance" (<<SUPP SPECIFIC PAGE(S) FOR QUOTATION>>ibid., ch. 12, VII<< "VII" STAND FOR? VOLUME VII OF THE COLLECTE " WRKS? SUPPLY COMPLETE INFORMATION FOR THIS VOLUME FOR THE REFERENCE LIST (IBID WOULD BE FOR 1936 GENERAL THEORY AS CITED AT BEGINNING OF PREVIOUS PARAGRAPH >>). Indeed, Akerlof and Shiller (2009) classify money illusion as an aspect of the five animal spirits that caused the $2008<<20{ }^{2009}$ ? OR “CAUSED THE RECENT..."?>> financial crisis, along confidence, fairness, temptation toward corrupt and antisocial behavior, and changing stories about the economy.

In the 1960s, most economists agree with the Keynesian hypothesis of money illusion among workers, without inquiring into its basis, and use it to explain the existence of the Phillips curve, which according Tobin (1967), is "in a sense a reincarnation in dynamic guise of the original Keynesian idea of 'money illusion' in the supply of labor. The Phillips curve says that increases in money wages-and more generally, other money incomes-are in some significant degree prized for themselves, even if they do not result in equivalent gains in real incomes." $<<$ PA@ FOR QUOTATION $>>$ Thus, this illusion justifies the existence of a negative relationship between inflation and unemployment: rising prices leads to declining real wages, and thus to a reduction in unemployment.

However, with the rise of the monetarist school in the late 1960s, this $\operatorname{tr}$ off disappeared since the money illusion hypothesis, in particular $<$ ? >> applied to workers, was abandoned by most economists. This choice was not based on empirical evidence that money illusion did not exist, but rather on the prevalent model of rational behavior. Indeed, if workers are rational and maximize their expected utility, they anticipate future inflation when negotiating their nominal wages and cannot be subject to money illusion. Admittedly, Friedman (1968) concedes that workers may inaccurately forecast inflation in thort term, and that if they underestimate the latter $<<$ SPECIFY "T LATTER" $>>$, the decline in real wages can reduce unemployment. The Phillips curve

${ }^{5}$ Ibid., chapter 21, I.<<CLARIFY SOUR SEE QUERY AT NOTE 2>> 
(enhanced with adaptive anticipations) thus reappears but only for the short term, after which the illusion dissipates and agents correct their errors. In the long term, workers do not make mistakes in their expectations; hence, money is neutral. In the short term, controlling the quantity of money ensures the absence of inflation (or at a low level), and thus maintains unemployment at its natural level.

The rational expectations revolution in the late 1970s discredited the hypothesis of money illusion, and its implications, from economics for a long time. Since rational individuals do not exhibit illusions or commit errors, there is nothing to study and the trade-off between inflation and unemployment disappeared, even in the short term. Lucas (1973) nevertheless conceded that money has a real but temporary impact on output, not because of money illusion strictly speaking, but due to a confusion among producers between a general rise in the price level attributable to expansionist monetary policy and an increase in the relative price of the goods they produce. Hence, money is neutral unless monetary authorities mislead agents with regard to the level of inflation and the credibility of monetary policy becomes a crucial stake. Nor is this absence of money illusion challenged by overlapping generations models that justify the existence of money by introducing liquidity constraints à la Diamond (1965) or by money search models à la Kiyotaki and Wright (1989). Money search models focus on the medium of exchange function of money, except in some models that show that inflation or a money-unit change could create a price illusion and have a favorable impact on welfare under certain conditions. ${ }^{6}$ Even Post Keynesian critiques about the neutrality of money relied on the endogeneity of money (Moore 1988) or on lags in adjustments (Trevithick, 1975), rather than on manay illusion, an hypothesis that, according to Davidson $(1999<<1999 \Omega$. 1999b? SEE QUERY IN REFERENCE LIST $>>$ ), is not required to reject the homogeneity postulate. ${ }^{7}$

However, in the past two decades, this consensus has largely disappeared. Some economists reconsider the relevance of money illusion partly because the stickiness of nominal wages and prices seem to be an important phenomenon and money illusion provides an explanation to this nominal inertia in addition to other factors such as menu costs or efficiency wages. Moreover, a lot of empirical or quasi-empirical evidence seems to support the occurrence of money illusion.

\footnotetext{
6 See Besancenot et al. (2009) and Diamond (1993).

7 See Wray $(1992)<$ C REFERENCE LIST $\gg$ for a survey of these approaches.
} 
The downward stickiness of nominal wages is revealed either at an aggregate level, with the help of quantitative data, or at an individual level, based on qualitative surveys. ${ }^{8}$ Using panel data from several Western countries, Card and Hyslop (1997) and Kahn (1997) showed that the distributions of changes in nominal wages are asymmetrical around zero. Fortin (1996) studied 1,149 large non-cost-of-living adjustment (non-COLA) union wages in Canada from 1992 to 1994 during a severe recession characterized by weak inflation (1.2 percent) and high unemployment (11 percent). His results underscore the small proportion of wage settlements involving wage cuts (5.7 percent), whereas nearly half of them froze wages (47 percent).

Qualitative surveys are used to ask agents directly about this nominal wage rigidity. Their results reveal, first, that resistance to a reduction in wages is frequent, even among managers, and second, that money illusion is an important factor of this resistance. Thus, the opinion surveys of Canadian households carried out by Kahneman et al. (1986) show that rules of fairness can play a role in wage stickiness, as suggested previously by Akerlof (1979) and Solow (1980). These rules are influenced by a type of money illusion considered a framing effect, as it reflects agents' sensitivity to the nominal framework. ${ }^{9}$ This illusion is clearly visible in the different answers to two questions that are identical in real terms: 62 percent of those surveyed believe that in a context of high unemployment and no inflation, it would be unfair for a struggling firm to cut wages by 7 percent, whereas 78 percent think that in a similar context of unemployment but with inflation of 12 percent, a 5 percent rise in wages would be acceptable.

Surveys of managers in another context confirm the influence of money illusion linked to a certain conception of fairness in wage stickiness. The results of a survey carried out by Blinder and Choi (1990), aimed at human resource managers (or equivalent) in 19 U.S. firms indicate that 47 percent of those surveyed consider it more equitable that real wages should be reduced due to inflation outstripping the increase in nominal wages, rather than a reduction in nominal wages in a zero-inflation context. Furthermore, 59 percent of these managers believe that workers share this conviction. When asked why, they suggest a psychological difference between taking away and not giving, rather than a poor understanding of real wages. These results are confirmed by interviews carried out by Bewley (1999) in Connecticut<<HOW IS "IN CONN TICUT"

8 See Akerlof (2002) and Akerlof and Shiller (2009).

9 See Kahneman and Tversky (1981). 
MEANINGFUL? BE MORE SPECIFIC, OR SUGGEST DELETING THOSE WORDS $>>$, which showed that managers only reduce nominal wages as a last resort, citing ethical reasons for this choice. Last, in a large sample of Swedish human resource managers surveyed by Agell and Bennmarker (2007), most of the respondents (94 percent) stated that in a context of high unemployment and no inflation, their workers would not accept a 5 percent cut in wages, whereas in the same circumstances but with an inflation rate of 10 percent, just half of the respondents believed that their workers would refuse a mere 5 percent increase in wages.

The same type of reluctance can play a role in price stickiness. Thus, a survey by Blinder (1994) on price adjustments showed that rigid prices are the norm: 65 percent of firms surveyed do not revise their prices or do so only once or twice a year. Moreover, in the ranking of 12 possible motivations for this rigidity, including various justifications drawn from economic theory, the leading reason cited is coordination failure (mentioned by 60 percent of respondents), 50 percent of the firms cite implicit contracts, defined as tacit agreements for price stability, perhaps out of "honesty" to the client, and 36 percent state that prices are fixed by explicit contracts. These findings are confirmed by a similar study in the eurozone, wherein the majority of firms surveyed change their prices only once a year, and implicit or explicit contracts are cited as the main factors for this rigidity (Fabiani et al., 2007). Money illusion clearly plays a role here in connection with considerations of ethics or fairness, as suggested by Okun (1981), in the psychological weight of these contracts. ${ }^{10}$ According to Tyran (2007), entrepreneurs' sensitivity to money illusion may also result in an aversion to nominal losses, which would justify downward stickiness of prices, as price cuts inevitably reduce profits.

Other studies show that a pure nominal shock as the euro introduction in January 2002 triggered significant real effects $<<\sqrt[6]{\text { PCK SUCH }}$ AS THE EURO INTRODUCTION..."? OTHER TE THIS IS UNCLEAR $>>$, thus discrediting the absence of the money illusion hypothesis. For instance, the European Central Bank observed in its 2002 annual report that the monthly change in prices in restaurants and cafes in the eurozone in January 2002 was more than three times as high as the average for the month of January over the period 1996-2001, and clearly higher than in EU countries that did not adopt the euro. These observations also apply to most other services.

10 See also Blinder et al. (1998). 
The changeover to the euro, viewed as a natural experimental in changing the nominal framework, also had consequences for various types of donations. Notably, Kooreman et al. (2004) showed that in 2000 and 2001, the growth in donations to a specific charity in the Netherlands (2.2 percent and 1.3 percent, respectively) was lower than inflation, whereas in 2002, donations substantially outpaced inflation (they rose 11.1 percent). Yet this sharp increase cannot be attributed to a corresponding rise in incomes, as the change in the real disposable income was virtually zero in 2002, nor can it be explained by a specific event. According to Kooreman et al., this effect is thus an example of money illusion. More specifically, people saved on cognitive effort by dividing previous guilder amounts by 2 rather than applying the exact guilder/euro conversion rate of 2.20371 , or preferred to round off their contribution up to the nearest 0.50 euro coin instead of giving the exact equivalent of a guilder, which would have required using several coins.

Cannon and Cipriani (2006) highlight similar effects of the euro introduction on church giving. Thus, in 2002, these donations grew by 11 percent in nominal terms in Italy, for GDP (gross domestic product) growth of 3 percent, and 13 percent in Ireland, for GDP growth of 10 percent. This implies stronger money illusion in Italy than in Ireland. These divergences can be attributed to different types of bounded rationality associated with the differences in the euro exchange rates: in every countrv except Ireland, the conversion to the euro led to lower numbers $<<<$ WHAT? $>$. So, the anchoring effect should result in greater spending everywhere, with lower spending only in reland. The marked increase in giving <<CLARIFY / CHURCH NATIONS? $>>$ in Italy and the continued use of the lira as a unit of account appear to support this type of effect. However, in Ireland, there was an increase in donations, but to a weaker degree than in Italy compared to income growth. This result provides weak support for a difference assessment effect at play in Ireland: when all nominal values increase proportionately, spending rises. Last, as a large portion of giving is done in round figures, banknotes and coins $<<$ PREVIOUS PART OF SENTENCE UNCI R / "... IN ROUND FIGURES, BANKNOTES AND COINS"? ANING BANKNOTES AND COINS ARE THE FIGURES (E.G., DONATIONS)? $>>$, these results are also partly attributable to rounding and threshold effects.

Showing that people gave more to charities in different countries after the changeover to the euro, these behavioral studies shed light on the impact of nominal changes on consumption exp itures that Keynes suggested it would depend<<"WHICH KEY S SUGGESTED 
WOULD DEPEND...'?>> on expectations in chapter 19 of his General Theory. These empirical findings are supported by various stylized facts. For instance, contracts seldom include indexation clauses to link future payments (debt, wages, rents, etc.) to the consumer price index or any other inflation index, and most government and corporate bonds are not inflation-indexed. This frequent absence of indexation is evidence that agents prefer to stipulate their rights and obligations in nominal terms. Ignoring the rate of inflation may be a convenient rule of thumb when inflation is low and stable but the real value of currencies has proven unstable historically. Thus, Christofides and Peng (2006) note that in Canada, from 1976 to 2000, across periods of high and weak inflation and varying uncertainty in the nominal and real value of money, only 19 percent of labor contracts in a large sample included an indexation clause, and when present, such clauses were generally incomplete, taking effect only ahoye a certain inflation level, for instance. According to Shiller et at. 207), this resistance or indifference to indexation is widespread worldwide, even in countries such as Turkey that have experienced high and variable inflation. 7 note-a few exceptions in periods of very high inflation, such as Chile, which implemented in 1980 an abstract unit of account (Unidad de Fomento, or UF), defined as the amount of pesos needed to buy the cost-of-living bundle. Since then, all forward contracts including future payments are stated in UFs and paid in pesos depending on the UF's value, which is published daily. It is difficult to explain why this reform has been so easily accented, and also why it has not been adopted in any other country. A sur carried out by the authors<<CLARIFY / SHILLER $\rightarrow$ AL.? INCLUDE CITE FOR "SURVEY" (AND INFORMATIO WR THE REFERENCE LIST IF NOT THE 1997 REFERENCE ALREADY INCLUDED>> of fairly educated individuals $<<$ RESTATE TH THE SURVEY WAS NOT ABOUT "FAIRLY EDUCATED IN IIDUALS"? >> in the United States and Turkey highlights that money illusion is, on the one hand, an important factor behind this resistance to indexation, and on the other hand, a complex phenomenon reinforced by perception errors, such as underestimating the potential uncertainty of inflation or the effects of inflation, which is often considered as an insidious disease that harms virtually everyone rather than causing arbitrary redistribution from creditors to debtors.

Moreover, money illusion is a widespread phenomenon in society, given the frequent confusion between real and nominal value in political discussions, societal debates, or media coverage (Akerlof and Shiller, 2009; Shafir et al., 1997). Even stock market investors, while<<“WHOSE'? 
"FOR Wथ M"?>> the-stakes are obviously very high, seem to suffer from a particular form of money illusion, discounting real cash flows at nominal discount rates as suggested by Modigliani and Cohn (1979). Indeed, recent time-series studies show that real indicators, such as stock dividend and earnings yields (the inverse of the price/earning ratio) are highly correlated with nominal bond yields (Asness, 2000; Sharpe, 2002). According Boucher (2006) and Campbell and Vuolteenaho (2003 <<2004 IN 2 FERENCE LIST >>), money illusion could also explain the negative correlation between inflation and stock valuation. Cohen et al. (2005) also support this hypothesis when distinguishing money illusion from changing attitudes of investors toward risk using the Sharpe-Lintner<<CITATION NEEDEQ ADD REFERENCE FOR SHARPE-LINTNER? $>>$ capital asset pricing model. Furthermore, professionals in the financial sector or prestigious financial institutions such as the U.S. Federal Reserve contribute to spreading this type of confusion as seen with the success of the "Fed model" (Asness, 2003). Indeed, this equity valuation model, which Alan Greenspan implicitly referred to in a speech in 1997<<ADD REFERENCE (TITLE, SP DH TO WHAT INSTITUTION, MONTH/DAY, URL IF AVAILA ONLINE >>, compares a real indicator (the earning yield on shares) to a nominal indicator (the yield on a 10-year Treasury note). When the first $\sigma$ s higher (lower) than the second, stocks are supposed $<<$ SUPPO $L Y$ ? $>>$ overvalued (undervalued). Despite being subject to money illusion, this model rapidly gained popularity as a means to< $@$ ? $>$ assessing the overall valuation of the stock market, although the Fed never acknowledged it officially. Money illusion is also invoked to explain speculative bubbles on real estate or financial markets. According to Haight (2007), the recent housing price bubble in the United States was supported by a long period of low inflation that create an environment conducive to predatory lending since home buyers watch the nominal rather than real rate and more particularly monthly payment ratio. His view that money illusion can be stabilizing in the presence of moderate rather than zero (or very low) inflation contrasts with those of Akerlof and Schiller (2009) and Bell and Quiggin (2006), who argued that money illusion associated with lower nominal rates played a role in promoting higher gearing $<<$ WOH DS MEANT? $>>$ and thus greater financial risks. Hence, behavioral findings on money illusion might be relevant to provide microecon foundations to some bubble tharies, such as those of $<<$ FIRST 2 ME $>>$ Minsky and $<<$ FIRST I IE $>>$ Kindleberger. 


\section{The psychology of money illusion: cognitive bias and neural correlates}

Experimental economics casts light on the empirical reality of money illusion by rying to $\mathrm{s}$ its existence at an individual level as a cognitive bias consisting<< hIIT EXISTS? >> in the confusion between real and nominal va (19). With this perspective in mind, Shafir et al. (1997) carried out an extensive survey, covering wages, transactions, and contracts, which proves that agents can fall prey to non-negligible money illusion in these various contexts. Shafir et al. show in particular that the majority of individuals in their survey think in nominal, rather than real, terms when asked to compare certain situations; for example, to determine whom among characters Adam, Ben, or Carl made the best deal in selling a house purchased for $\$ 200,000$ at different prices in different inflationary environments. Indeed, 53 percent of the subjects considered that Adam earned the least money, even though he in fact earned the most in real terms $(+2.67$ percent) but the least in nominal terms ( -23 percent). Conversely, 48 percent believe that Carl made the best deal, while in fact he lost the most money in real terms ( -1.67 percent) but earned the most in nominal terms (+23 percent). In addition, most of these participants expected that other people would also be subject to money illusion. Shafir et al. analyze this strong money illusion effect as a framing effect reflecting agents' preference for the nominal framework given its salience and easiness to process, even though they may also grasp the real framework. However, they observe that the favored cognitive framework may vary depending on the context and the decision-maker's experience, and that in most cases, agents mix the nominal and real frames, at least partially. In particular, it would appear that real prices are calculated and taken into account by agents when it becomes crucial to keep track of them, as during periods of hyperinflation or for long-term contracts. The conclusions of Shafir et al. are notably supported by the findings of Fehr and Tyran (2001, 2007, 2008), who show that subjects in their price-setting game experiments are sensitive to a certain degree of money illusion once they are shown gains expressed in nominal, rather than real, terms.

The existence of the phenomenon of money illusion at the individual level suggests that economists might do well to understand the psychological functioning of this cognitive bias. However, this multidisciplinary approach is probably limited by the fact that until now, psychological and neurobiological data, obtained with a view to understanding our money-related behavior, have had a very low impact on the analysis and modeling of the nature and role of money in economics. Yet the 
question is to know whether this data can have an impact on economic theory. Economists both well versed in economic theory and updating their knowledge « "AND IN UPDAT CP...?BUT NOT SUREIUNDERSTAND / POSSHBLE TO CLAKHY? $\gg$ about rapidly evolving findings in cognitive neuroscience can emit the most informed answers to this question. In particular, they have to evaluate the support neuroscience can provide to reject or admit some behavioral hypotheses, such as that of Davidson (2010)<<NOT IN REFERE 2 E LIST $>>$, who points out that a recent functional magnetic resonance imaging (fMRI) study "provides strong support for the Post Keynesian view that the ergodic axiom must be rejected if one is to understand decision making in a modern money-using entrepreneurial economic system" $<<$ IDSON QUOTE? SUPPLY PAGE $\gg>$ by demonstrating that decision making under ambiguity (uncertainty with unknown probabilities à la Keynes) and risk (uncertainty with known probabilities) are supported by distinct brain mechanisms. ${ }^{11}$ In a less systematic fashion, economic psychology studies tend more toward highlighting a variety of factors that can influence a phenomenon such as money illusion, rather than revealing a few basic and shared ingredients of our mental representation of money. For instance, using the experimental protocol proposed by Shafir et al. (1997), a study by Przybyszewski and Tyszka (2007) shows that money illusion is affected by an individual's emotional attachment to a given currency. Prices expressed in a currency that triggers a stronger positive affective reaction are perceived as higher than equivalent prices expressed in a different currency with a more negative emotional connotation. We can suppose that money has symbolic dimensions that go beyond its instrumental properties as a medium of exchange, a unit of account, and a store of value. This emotional or symbolic value of money interferes with its purely instrumental value; the former adds or subtracts from the latter depending on the emotional valence of the money stimulus in question. However, the problem lies in knowing whether these psychological factors are purely contingent and must, due to their irregularity, be stripped out of economic theorization of money, or, conversely, if the psychological reality of money is sufficiently stable to provide an explanation for a phenomenon such as money illusion that economic analysis cannot entirely ignore.

Cognitive sciences have investigated the emotional and symbolic aspects, on the one side, and the instrumental value of money, on the other side, formulating different hypotheses on how these two dimensions

11 See Huettel et al. (2006). 
articulate. We suggest the following hypothesis: money illusion is an anomaly rooted in an imbalance between these two dimensions, with one systematically taking the upper hand. As shown by Shafir et al. (1997), most subjects juxtapose two representations (one nominal and the other real), which may replicate the dichotomy between money's emotional connections and its instrumental dimension. However, the predominance of the illusion lies in the difficulty in inhibiting the nominal representation or frame that spontaneously comes to mind. It is as if two systems for understanding money stimuli coexisted in individuals' minds, with no systematic underlying representation.

It is hard to envisage a hierarchy between an instrumental conception of money and a more instinctive one. The success of money throughout history may have been favored by the potentially addictive hold it can exert on the human species. Conversely, for a given object to be able to fulfill certain desires or impulses, the subject may have to lucidly recognize certain functions or potential uses that would be the actual source of motivation. In the distinction between "money as drug" and "money as tool" established in cognitive science by Lea and Webley (2005), "money as drug" has been more largely explored in behavioral and neuroeconomic studies. However, Lea and Webley's synthetic approach provides theoretical elements for an analysis of the relation between these two dimensions of money, at the intersection of which money illusion may lie as this approach does not necessarily call for mutually exclusive alternatives. Our attitudes toward money can alternate between various cognitive and affective poles. People's oscillations between these two poles imply that determinate solutions of general equilibrium models are unlikely to be valid models of actual behavior. The "irrationality" of financial bubbles may also be tracked back to unpredictable changes in how people value assets due to the fact they have no firm cognitive basis upon which hold a particular valuation with certainty. Modern behavioral economists rely on psychological models like the opposition between so-called System 1 affective and automatic mental processes and System 2 cognitive and analytic processes, as in, for example, Kahneman (2003). But we should not conceal a, rarely made explicit, genealogy stemming back to Keynes's classical opposition between calculation and sentiment. ${ }^{12}$ Money illusion may be viewed as a difficulty in considering in a lucid and rational way the nominal value of a money stimulus, hence as the correlative difficulty in rationally considering the real, and thus instrumental, value that corresponds to the nominal value.

${ }^{12}$ See the passage quoted earlier.<<C $\Omega$ IFY / WHAT, WHERE? $>>$ 
To apply psychological terminology used to explain cognitive biases (e.g., framing effects), nominal representations of prices, due to their salience, require a lower cognitive processing cost than processing real values: nominal values form "System 1" representations that do not automatically translate into "System 2" (i.e., rational) representations (see Kahneman, 2003). System 1 representations have an immediate emotional impact and must be blocked in order to realize the cognitive bias resulting from their processing. In a 5 rard-looking article-on research programs that could fall within the 2 pe of neureeconomies, Camerer et al. (2005) highlighted the hedonic rather than instrumental relationship that people generally have with money: "People value monev without carefully computing what they plan to buy with it." $<<$ PAA FOR QUOTE $>>$ Money's utility is more linked to an experience or a direct sensation of pleasure than to an assessment of the goods that the agent can acquire therewith. For instance, the authors consider the phenomenon of prepaid vacations to be a particular type of money illusion, whereby people tend to enjoy their trip more if the longer have to worry about paying for it. According to them $<<$ CAM 2 R ET AL.? $>>$, neuroeconomics can provide evidence for these behavioral hypotheses insofar as it reveals brain activity linked to pleasure or relief at making these payments, which are disconnected from the actual consumption that they make possible.

Neuroscientists have hypothesized the existence of a single neural reward representation, encompassing money reward, but also other types of reward. Thus, the concept of "common neural currency," put forth by Montague and Berns (2002), refers to the similarity between brain activity observed for a range of stimuli, including notably money rewards, but also food, sexual, or social rewards (building up one's good reputation is an example of a social reward). The neural model proposed by Montague and Berns is based on the assumption that the common responses to various types of stimuli observed in the orbitofrontal and striatal circuits are derived from the conversion of disparate future rewards into a sort of uniform "internal currency." Admittedly, there is no reason to think, a priori, that money is a specific reward in terms of the brain activity it can trigger in an individual, yet most recent neuroeconomic studies have merely cast light on the motiy nal aspects of money, either intentionally or incidentally (i.e., $<<$ E. ? $>>$ when rewarding the performance of subjects in an experiment). Money is thus processed by the brain's reward circuit in a fairly similar way to primary biological stimulants such as food or sex (De Quervain et al., 2004), but it can also exert an unconscious motivation for behavior (Pessiglione et al., 2007). 
A more specific study of the neural substrates of money illusion has been proposed by Weber et al. (2009). Weber et al. used fMRI technology in order to observe the cerebral mechanisms potentially involved in money illusion as expressed by an individual. Participants in their experiment were subject to two distinct experimental conditions. In both conditions, the economic structure was identical in real terms, but varied in nominal terms. The subjects obtained monetary units by carrying out an incidental task. This income was not paid in the form of money, but rather in purchasing power that could be spent on a relatively broad, but fixed, catalog of products. The catalogs for the two conditions were identical except that all of the prices were 50 percent higher in one of the two (labeled the "high price condition"). The difference between the two conditions was created as follows: for all income received by the subjects after accomplishing the incidental task and used to purchase products in the "low price condition," the experimenters set a level of income exactly 50 percent higher that could be used to acquire products in the high price condition, for prices also 50 percent higher. The real value of the products was thus unchanged, with only the nominal value (or prices and corresponding income) varying between the two conditions.

The hypothetical process of Weber et al. (ibid.) consists of inquiring whether there is an observable dissociated effect on the brain circuits typically involved in processing and assessing rewards caused by the nominal and real values of the income acquired and spent during the experiment. The reward circuit plays a crucial role in learning and decision making. Thus, the question is whether the two distinct nominal frames given for a single real economic structure (i.e., the constant relation between subjects' income and the prices of products in the catalog) trigger different effects within these brain circuits. As the real structure is fixed, Weber et al. hypothesized that any modification in brain activity between the two conditions would be attributable to the change in the nominal framework. The accuracy of this hypothesis is surely open for discussion, or at least the robustness of the conclusions anticipated through its formulation, because we can imagine that a similar experiment manipulating the real economic structure while maintaining the nominal value would also produce differentiated brain activity, which would not suggest any sort of illusion, but instead that decision-making or assessment processes are rooted in reality. In the terms of Weber et al., the absence of money illusion should in principle be reflected in an absence of differentiated brain activity in the processing of value linked to this purely nominal change. 
However, it is clear that interpreting differences in brain activity observed in this experimental framework in terms of money illusion in the narrow sense is overly deterministic. This interpretation is nevertheless favored by the fact that the neurobiological observations are limited to the reward circuit, on the one hand, and by the correlation of these neural activities with independent behavioral results on a replication of the experiment initially run by Shafir, Tversky and Diamond $<<$ CL $\mathbb{Q}$ FY / SHAFIR, DIAMOND, AND TVERSKY 1997 MEANT? $>>$, on the other hand. For the former, it may appear probable, or even tautological, that a change in brain activity linked to reward corresponds to a differentiated assessment of the value of money stimuli between the two experimental conditions in question. Yet if the real value does not change, the subjects are suffering from money illusion. However, what this reasoning still leaves undetermined is the cause of a specific impact of nominal frames on the reward circuit and, moreover, the reasons why this cerebral impact of nominal frames is such that it prevents the real economic structure from being taken into account.

Weber et al. (2009) highlight that one of the crucial areas of the brain's reward circuit, the ventromedial prefrontal cortex, which is associated with the assessment and anticipation of goods, is subject to money illusion, as defined by the researchers in this experiment. Activity observed in this area of the brain was much higher in the high price condition than in the low price condition. These observations suggest that money illusion has specific biological anchoring. They point to money illusion not just as a behavioral anomaly visible on an individual level, but especiallymore radically - as an infra-individual neurobiological phenomenon. This result could be related to De Martino et al.'s (2006) investigation of the neurobiology of framing effects. Money illusion is an instance of a framing effect in the sense that the format in which real monetary transactions are presented has an incidence on their evaluation. Nominal formats are most certainly frames that involve a higher activity of the neural emotional system, as De Martino et al. find that the framing effect was specifically associated with amygdala activity. By contrast, they show that higher orbitofrontal and prefrontal neural activities, which are typically connected with a cognitive appraisal of a situation, predict a reduced susceptibility to the framing effect. This dual account of neural activities underpinning the money illusion connects its experimental investigation to well-known theoretical frameworks in psychology and behavioral economics. 


\section{Conclusion}

Recent research about money illusion essentially presents empirical evidence based on quantitative data or qualitative surveys, supported by stylized facts. In the absence of a theoretical basis, experimental economics contributes to a behavioral explanation for money illusion that reveals agents' preferences and the fact that it results from the use of various heuristics (the framing effect, anchoring effect, etc.).

Economists should be sensitive to psychological and even biological explanations of this prevalent bias. The purely instrumental approach to money used in standard economic theory seems to be discredited by a neurobiological study that confirms a behavioral reality, namely, that a purely nominal change in a purchasing situation has a specific impact on an area of the brain's reward circuit, which plays a key role in decision making. This biological fact would be a physical demonstration of Keynes's "animal spirits." Recognizing the reality of this hedonic or emotional dimension of money, which lies outside the scope of homo economicus, has substantial theoretical and practical implications.

This new set of data supports the idea, based on numerous anthropological, historical, and sociological studies, that money does not belong entirely to the trading sphere of human activity. The hypothesis that money retains properties inherited from primitive sociological structures warrants further investigation by economists, in particular the fact that money's archaic nature is visible through money illusion. More generally, economists may be invited through the positive recognition of this set of data to adapt their theories rather than expecting that this bias can be eliminated by fostering acquaintance of the public with their own normative theories.

In addition, these findings appear to place money illusion outside one's voluntary control and discard the possibility of an efficient institutional design to eliminate it. One could assert that the existence of a biological explanation for money illusion makes it more difficult, a priori, to implement policies aimed at eliminating this anomaly in society. Broadly speaking, if money illusion were only a distortion in reasoning, that is, a "simple" cognitive bias resulting in a behavioral anomaly, the prevalence of this bias could be reduced thanks to socioeconomic behavioral reform programs, along the lines of proposals put forth by the "liberal paternalism" (Sunstein and Thaler, 2003) or "asymmetric paternalism" (Camerer et al., 2003) movements. But its neurobiological and evolutionary anchoring seems to plead for an adaptation of institutions to 
that bias rather than for an attempt at eliminating it through adequate institutional design.

Measures that could be considered include the creation of indexed units of account, as in the Chilean example, of markets to hedge inflation risk, such as the European inflation futures market at the Chicago Mereantile Exchange $\$ C P<<$ THE ABBREVIATION FOR THE CHICAGO MERCANTILE EXCHANGE IS CME / WHAT IS HICP FOR? HARMONISED INDEX OF CONSUMER PRICES? IF SO, NOT SURE HOW THAT WORDING FITS HERE / POSSIBLE TO CLARIFY? >), as recommended by Shiller, or of mandatory revaluation measures, such as those that cover rents or child support payments in some countries. Education can also play a role, as some surveys show that economists do not suffer from money illusion (Shiller et al., 1997), which attests to the impact of learning on this issue.

In the meantime, the real effects of money illusion should not be ignored since a large number of financial transactions or contracts are denominated and exchanged in money terms but not indexed to prices, as well as the presentation of company accounts, determining corporate income tax or financing decisions, and because even a low level of money illusion appears to have a significant impact on agents' choices (Akerlof and Yellen, 1985; Fehr and Tyran, 2001, 2007). By testing these effects and taking them into account in models, we would be able to better understand and assess price and wage stickiness, speculative bubbles on real estate or financial markets, and real effects of nominal shocks.

\section{REFERENCES}

Agell, J., and Bennmarker, H. "Wage Incentives and Wa $C$ igidity: A Representative View from Within." Labour Economics, 2007, $14<<$ IS — IND/OR SEASON $>$, 347-369.

Akerlof, G.A. "The Case Against Conservative Macroeconomics: An Inaugural Lecture.” Economica, 1979, 46 (183), 219-237.

- "Behavioral Macroeconomics and Macroeconomic Behavior." American Economic Review, 2002, 92 (3), 411-433.

Akerlof, G.A., and Shiller, R.J. Animal Spirits: How Human Psychology Drives the Economy, and Why It Matters for Global Capitalism. Princeton: Princeton University Press, 2009.

Akerlof, G.A., and Yellen, J. "Can Small Deviations from Rationality make Significant Differences to Economic Equilibria?” American Economic Review, 1985, 75 (4), 708-720.

Asness, C. "Stocks Versus Bonds: Explaining 7 quity Risk Premium." Financial Analysts Journal, 2000, $56<<$ ISSUE AND/O1 20 ASON $>>$, 96-113. "Fight the Fed Model." Journal of Portfolio Management, 2003, $30<[S$ UE AND/OR SEASON>>, 11-24. 
Bell, S., and Quiggin, J. "Asset Price Instability and Policy Responses: The Legacy of Liberalization." Journal of Economic Issues, 2006, 40 (3), 629-649.

Besancenot, D.; Rocheteau, G.; and Vranceanu, R. "Search, Price Illusion and Welfare." Journal of Macroeconomics, 2000, 22 (1), 109-124.

Bewley, T. Why Wages Don't Fall During a Recession. Cambridge: Harvard University Press, 1999.

Blinder, A.S. "On Sticky Prices: Academic Theories Meet the Real World." In N.G. Mankiw (ed.), Monetary Policy. Chicago: University of Chicago Press, 1994, pp. 117-154.

Blinder, A.S., and Choi, D.H. "A Shred of Evidence on Theories of Wage Stickiness." Quarterly Journal of Economics, 1990, 105 (4), 1003-1015.

Blinder, A.S.; Canetti, E.; Lebow, D.; and Rudd, J. Asking About Prices: A New Approach to Understanding Price Stickiness. New York: Russel Sage Foundation, 1998.

Boucher, C. "Stock Prices-Inflation Puzzle and the Predictability of Stock Market Returns." Economics Letters, 2006, 90 (2), 205-212.

Eamerer, OC Dowenstein, G.; and Prelec, D. "Neurd L omies: How Neurescience ean Inform [D homies." Journal of Economic Literature, 2005, $43 \ll$ ISSUE AND/ OR SEASON $>>$, 9-64.

Camerer, C.; Issacharoff, S.; Loewenstein, G.; O’Donoghue, T.; and Rabin, M.

"Regulation for Conservatives: Behavioral Economics and the Case for Asymmetric Paternalism." University of Pennsylvania Law Review, 2003, 1151 (3), 1211-1254.

Campbell, J.Y., and Vuolteenaho, T. "Inflation Illusion and Stock Prices." American Economic Review, 2004, 94 (2), 19-23.

Cannon, E., and Cipriani, G.P. "Euro-Illusion: A Natural Experiment." Journal of Money, Credit and Banking, 2006, 38 (5), 1391-1403.

Card, D., and Hyslop, D. “Does Inflation 'Grease the Wheels' of the Labor Market?' In C.D. Romer and D.H. Romer (eds.), Reducing Inflation: Motivation and Strategy. Chicago: University of Chicago Press, 1997, pp. 195-242.

Christofides, L.N., and Peng, C. "Contract Duration and Indexation in a Period of Real and Nominal Uncertainty." Labour Economics, 2006, 13 (1), 61-86.

Cohen, R.B.; Polk, C.; and Volteenaho, T. "Money Illusion in the Stock Market:

The Modigliani-Cohn Hypothesis." Quarterly Journal of Economics, 2005, 120 (2), 639-688.

Davidson, $\mathrm{p}$ "Rehavioral Economists Should Make a Turn and Learn from Keynes and Post K 12 sian Economists." Journal of Post Keynesian Economics, Summer 1999 a, 21 , 1,37 , 588.

- "Keynes' Principle of Effective Depand Versus the Bedlam of the New Keynesians." Journal of Post Keynesian Eco 20 cs, Summer 1999b, 21 (4), 571588. <<YEAR, VOLUME, ISSUE, PAGE IANGE IDENTICAL TO PREVIOUS REFERENCE / VERIFY BOTH, SUPPLY APPROPRIATE CHANGES / MAKE SURE BOTH ARE CITED OR UNCITED REFERENCE NEEDS TO BE DELETED $>>$

De Martino, B.; Kumaran, D.; Seymour, B.; and Dolan, R.J. "Frames, (6ia es, and Rational Decision-Making in the Human Brain." Science, $<<$ MONTH A DAY FOR THIS MAGAZINE $\gg>2006,313,684-687$.

De Quervain, D.; Fischhacher, U.; Treyer, V.; Schellhammer, M.; Schnyder, U.; Buck, A.; and Fehr, 1 he Neural Basis of Altruistic Punishment." Science, <<MONTH AND D IOR THIS MAGAZINE>> 2004, 305, 1254-1258. Diamond, P.A. "National Debt in a Neo-Cl $\&$ al Growth Model." American Economic Review, 1965, $55<<$ ISSUE AND/ONSEASON $>>$, 1126-1150. "Search, Si Prices and Inflation." Review of Economic Studies, 1993, 60 $<<$ ISSUE AND/OR SPD ASON $>>, 53-68$. 
Fabiani, S.; Loupias, C.S.; Martins, F.M.M.; and Sabbatini, R. (eds.). Pricing Decisions in the Euro Area: How Firms Set Prices and Why. Oxford: Oxford University Press, 2007.

Fehr, E., and Tyran, J.-R. "Does Money Illusion Matter?” American Economic Review, 2001, 91 (5), 1239-1262.

. "Money Illusion and Coordination Failure." Games and Economic Behavior, 2007, 58 (2), 246-268.

_. "Limited Rationality and Strategic Interaction: The Impact of the Strategic Environment on Nominal Inertia." Econometrica, 2008, 76 (2), 353-394.

Fortin, P. “The Great Canadian Slump.” Canadian Journal of Economics, 1996, 29 (4), 761-787.

Friedman, M. “The Role of Monetary Policy.” American Economic Review, 1968, 58 (1), 1-17.

Haight, A.D. "A Keynesian Angle for the Taylor Rule: Mortgage Rates, Monthly Payment Illusion, and the Scarecrow Effect of Inflation." Journal of Post Keynesian Economics, Winter 2007-8, 30 (2), 259-277.

Huettel, S.A.; Stowe, C.J.; Gordon, E.M.; Warner, B.T.; and Platt, M.L. "Neural Signatures of Economic Preferences for Risk and Ambiguity." Neuron, 2006, 49 (5), $765-775$.

Kahn, S. "Evidence of Nominal Wages Stickiness from Microdata," American Economic Review, 1997, 87 (5), 993-1008.

Kahneman, D. "Maps of Bounded Rationality: Psychology for Be $\mathrm{dral}$ Economics." American Economic Review, 2003, 93 <<ISSUE AND/0 EASON>>, 1449-1475 Kahneman, D., and Tversky, A. "The Framing of Decisions and the Psychology
Choice." Science, New Series<<IS “NEW SERIES" A SUBTHLE? $>>,<<M$ AND DAY FOR THIS MAGAZINE $>$ 1981, 211 (4481), 453-458.

Kahneman, D.; Knetsch, J.; and Thaler, T. "Fairness as a Constraint on Profit Seeking: Entitlements in the Market." American Economic Review, 1986, 76 (4), 728-741.

Kiyotaki, N., and Wright, R. "On Money as a Me IIII of Exchange." Journal of Political Economy, 1989, 97 <<ISSUE AND/OR SL DN>> 927-954.

Kooreman, P.; Faber, R.; and mans, H. "Charity Donations and the Euro Introduction-Some Quasi Exper tal Evidence on Money Illusion," Journal of Money, Credit, and Banking, 2004, 30 <ISSUE AND/OR SEASON>> 1121-1124.

Lea, S.E.G., and Webley, P. "Money as Tool, Money as Drug: The Biologic $\mathrm{c}$ chology of a Strong Incentive." Behavioral and the Brain Sciences, 2005, $29<<\mathrm{E}$ AND/OR SEASON $>>161-209$.

Leontief, W. "The Fundamental Assumptions of Mr. Keynes' Monetar ory of Unemployment," Quarterly Journal of Economics, 1936, $51<<$ ISSUE /OR SEASON $>$ 192-197.

Lucas, R.E. "Some International Evidence on put-Inflation Tradeoffs." American Economic Review, 1973, $63<<$ ISSUE AND/(D) EASON $>>326-334$.

Modigliani, F., and Cohn, R. "Inflati@ ational Valuation and the Market." Financial Analysts Journal, 1979, 35 <<ISSUE D/OR SEASON $>>24-44$.

Montague, P.R., and Berns, G.S. "Neural Economics an Biological Substrates of Valuation." Neuron, 2002, 36 <<ISSUE AND/OR SEA 20 > 265-284.

Moore, B. Horizontalists and Verticalists: The Macroeconomics of Credit Money. Cambridge: Cambridge University Press, 1988.

Okun, A.M. Prices and Quantities: A Macroeconomic Analysis. Washington, DC: Brookings Institution Press, 1981. 
Patinkin, D. "The Indeterminacy of Absoly $@$ ices in Classical Economic Theory." Econometrica, 1949, 17 < <ISSUE AND/OK SEASON>> 1-27.

. Money, Interest and Prices: An Integration of Monetary and Value Theory. Evanston, IL: Row, Peterson and Company, 1956.

Pessiglione M.; Schmidt, L.; Draganski, B.; Kalisch, R.L.H.; Dolan, RI · and Frith, C.D. "How the Brain Translates Money into Force: A Neuroimaging S of Subliminal Motivation." Science, <<MONTH AND DAY FOR THIS MA ZINE〉> 2007, 316 (58 $04-906$.

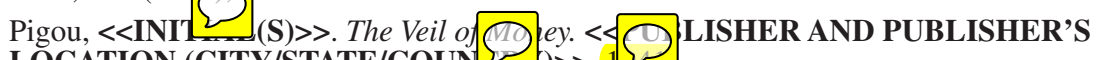
LOCATION (CITY/STATE/COUN $>>$, 1

Przybyszewski, K., and Tyszka, T. "Emotional Factors in Currency Perception.” Journal of Consumer Policy, 2007, 30 (4), 355-365.

Shafir, E.; Diamond, P.; and Tversky, A. "Money Illusion." Quarterly Journal of Economics, 1997, 112 (2), 341-374. [Reprint in D. Kahneman and A. sky, Choices, Valtues, and Frames. Cambridge: Cambridge University Press, 200 2 FVERIFY 1997 VERSION USED FOR THE CURRENT PAPER / IF KEEP THE "REPRINT" INFO, SUPPLY PAGE RANGE FOR THE CHAPTER IN THAT BOOK $>>$ ]

Sharpe, S.A. "Reexaminig Stock Valuation and Inflation: The Implications of Analysts Earnings Forecasts." Review of Economics and Statistics, 2002, $84<<$ ISSUE AND/ OR SEASON $>>$, 632-648.

Shiller, R.J.; Sehultze, C.L.; and Hall, R.E."Publi R istance to Indexation: A Puzzle." Brookings Papers on Economic Activity, 2, 1, 159-228.

Solow, R.M “On Theories of Unemployment." American Economic Review, 1980, 70 (1), 1-11.

Sunstein, C.R., and Thaler, R.H. "Libertarian Paternalism Is Not an Oxymoron." University of Chicago Law Review, 2003, 70 (4), 1159-1202.

Tobin, J. "Unemployment and Inflation: The Cruel Dilemma." In A. Phillips and O.E. Williamson (eds.), Prices: Issues in Theory and Public Po Cy. $<<$ CITY >>: University ef Pennsylvania Press, 1967, <<PAGE RANGE FOR CH 2 ER >>.

_. "Inflation and Unemployment." American Economic Review, 1972, 62 (1), $1-18$.

Trevithick, J.A. “Keynes, Inflation and Money Illusion.” Economic Journal, 1975, 85 (337), 101-113. Tyran, J.-R. "Money Illusion and the Market." Science, $<<$ MONT A D DAY FOR
THIS MAGAZINE $>>2007,314$ (5841), 1042-1043.

Weber, B.; Rangel, A.; Wibral, M.; and Falk, A. "The Medial Prefrontal Cortex Exhibits Money Illusion.” PNAS, 2009, 106 (13), 5025-5028. 
